\title{
Revascularisatio az aortában, a veseartériákban és az alsó végtagok artériás rendszerében
}

\author{
Nagy Csaba dr. ${ }^{1}$ - Király István dr. ${ }^{1}$ - Bánsághi Zoltán dr. ${ }^{2}$ \\ Doros Attila dr. ${ }^{3}$ \\ ${ }^{1}$ Markusovszky Egyetemi Oktatókórház, Központi Radiológiai Osztály, Szombathely \\ ${ }^{2}$ Szent Imre Egyetemi Oktatókórház, Képalkotó Diagnosztikai Osztály, Budapest \\ ${ }^{3}$ Semmelweis Egyetem, Általános Orvostudományi Kar, Transzplantációs és Sebészeti Klinika, Budapest
}

\begin{abstract}
A revascularisatio egy akutan vagy krónikusan elzáródott, beszúkült ér átjárhatóságának visszaállítását jelenti. A sebészi módszerek és gyógyszerek mellett évtizedek óta rendelkezésre állnak és folyamatosan fejlődnek azok a minimálisan invazív módszerek, amelyek jelentős részét az intervenciós radiológia fejlesztette ki és alkalmazza. Az innovatív szakmák bizonyos szempontból hátrányban vannak, mert sokszor forradalmi újításaik csak lassan jutnak el az általános elfogadottsághoz, és a nagy populáción végzett tanulmányok gyakran egyáltalán nem vagy csak késéssel végezhetők el. Mindezek ellenére ma már elfogadott és bizonyított a szerepük az aorta, valamint a renalis és perifériás artériák betegségeiben, amelyeket a szerzók ebben a közleményben elemeznek. Orv. Hetil., 2015, 156(17), 665-673.
\end{abstract}

Kulcsszavak: atherosclerosis, renovascularis hypertonia, kritikus végtagischaemia, ballonos tágítás, stentbehelyezés

\section{Revascularisation therapies of the aorta and renal and lower limb arteries}

Revascularisation aims to create a patent lumen in an acutely or chronically occluded or stenosed vessel. Interventional radiology has developed and used minimally invasive methods for decades concurring surgical methods and medical therapy. Innovative fields in healthcare may be handicapped since revolutionary solutions usually gain wide acceptance slowly and the results of randomized controlled trials are reported late. At present endovascular recanalization, dilatation and stent placement have achieved a well-established role in the treatment of stenosis or occlusion of the aorta, and renal and peripheral arteries.

Keywords: atherosclerosis, renovascular hypertension, critical limb ischemia, balloon angioplasty, stent implantation

Nagy, Cs., Király, I., Bánsághi, Z., Doros, A. [Revascularisation therapies of the aorta and renal and lower limb arteries]. Orv. Hetil., 2015, 156(17), 665-673.

(Beérkezett: 2015. február 6.; elfogadva: 2015. február 21.)

\section{Rövidítések}

$\mathrm{BTK}=$ térd alatti artériák; CLI = kritikus végtagischaemia; CTA = CT-angiográfia; DSA = digitális szubtrakciós angiográfia; MRA = MR-angiográfia

Az intervenciós radiológia első nemzetközi és hazai sikereit beszúkültt, elzáródott artériák kitágításával, kinyitásával érte el. Az elmúlt évtizedekben és napjainkban is je- lentős technikai fejlesztés zajlik. Jobb eszközökkel tartósabb eredményt érünk el, ha lehet, még kisebb megterheléssel, még rövidebb idő alatt. Kellő adat áll már rendelkezésünkre, hogy alátámassza a mindennapi munkánk során egyébként is megélt sikereket. A szerzők az alábbiakban az aorta, az arteria renalis, valamint az alsó végtagartériák kezelési lehetőségeinek egy részét fogják csokorba. 


\section{$\mathrm{Az}$ aorta szúkületeinek és elzáródásainak endovascularis kezelése}

$\mathrm{Az}$ alsó végtagi artériás keringészavar esetén használt alapfogalmak:

- Claudicatio intermittens: Fizikai terheléskor jelentkező alsó végtagi izomfájdalom, amely pihenésre szűnik, hátterében veróérbetegség (szúkület vagy elzáródás) áll.

- Kritikus végtagischaemia: Hátterében az alsó végtag olyan kritikusan alacsony artériás perfúziója áll, amelynek következtében nyugalmi fájdalom, szövethiány vagy nem gyógyuló fekély alakul ki.

- Akut ischaemia: A végtag hirtelen kialakuló vagy gyorsan romló perfúziócsökkenése, amely a végtagvesztés veszélyével fenyeget $[1,2]$.

A perifériás érbetegségek előfordulása a populációban 12-14\%. Gyakorisága az életkor előrehaladtával növekszik, így a 75 éves kor felettiek ötöde érintett lehet. Claudicatio intermittensben szenvedő betegek 7,5\%-ánál alakul ki kritikus végtagischaemia [3]. Kialakulását számos kockázati tényező elősegítheti, úgymint az előrehaladott életkor, hypertonia, diabetes mellitus, dohányzás, elhízás, mozgásszegény életmód, hyperlipidaemia vagy az emelkedett homociszteinszint [1]. A perifériás érbetegség csökkenti a fizikai teljesítőképességet és rontja az életminőséget [3]. Claudicatio intermittens hátterében az aorta szűkülete, az infrarenalis aorta elzáródása (Leriche-szindróma), illetve az alsó végtagi artériás rendszer betegségei állhatnak. Az aorta lumenét szúkítő betegségek esetén a leggyakoribb tünet a terheléskor jelentkező farpofa- vagy a lábikragörcs. Ritkábban alakul ki kritikus végtagischaemia vagy a microembolisatio kapcsán blue toe szindróma.

$\mathrm{Az}$ aorta stenoocclusiv betegségének kezelése lehet mütéti vagy endovascularis. Az aortobifemoralis graft vagy endarterectomia 5 éves nyitva maradása 90-95\%-os, a mütéti halálozás azonban elérheti a 2-5\%-ot [4]. Magas kockázatú betegek esetében a stentimplantáció és a ballonos tágítás biztonságos megoldásnak bizonyult ( 1 . ábra), sikeres technikai és klinikai eredménnyel, mindemellett kedvező hosszú távú kimenetelt biztosít [5]. Az endovascularis kezelés előnyös megoldást jelent, tekintettel arra, hogy a beavatkozás során nincs szükség altatásra, a hasüreg megnyitására, hosszú posztoperatív kórházi kezelésre, rehabilitációra, és nem utolsósorban jelentősen alacsonyabb a perioperatív halálozás. A beavatkozás indikációja megegyezik a mütétével, azaz az életminőséget befolyásoló claudicatio vagy kritikus végtagischaemia. A beavatkozás előtt DSA, CTA vagy MRA végzendő a szúkület vagy elzáródás pontos helyének és kiterjedésének tisztázására. A beavatkozás rendszerint transfemoralis vagy transbrachialis behatolásból végezhető. A ballonos tágítás egy ballonnal vagy két - kissing (egymás melletti) pozícióban bevezetett - ballonnal történik. A stentimplantáció atheroscleroticus szúkületek esetén jó hosszú távú nyitva maradást biztosít [5]. A nem

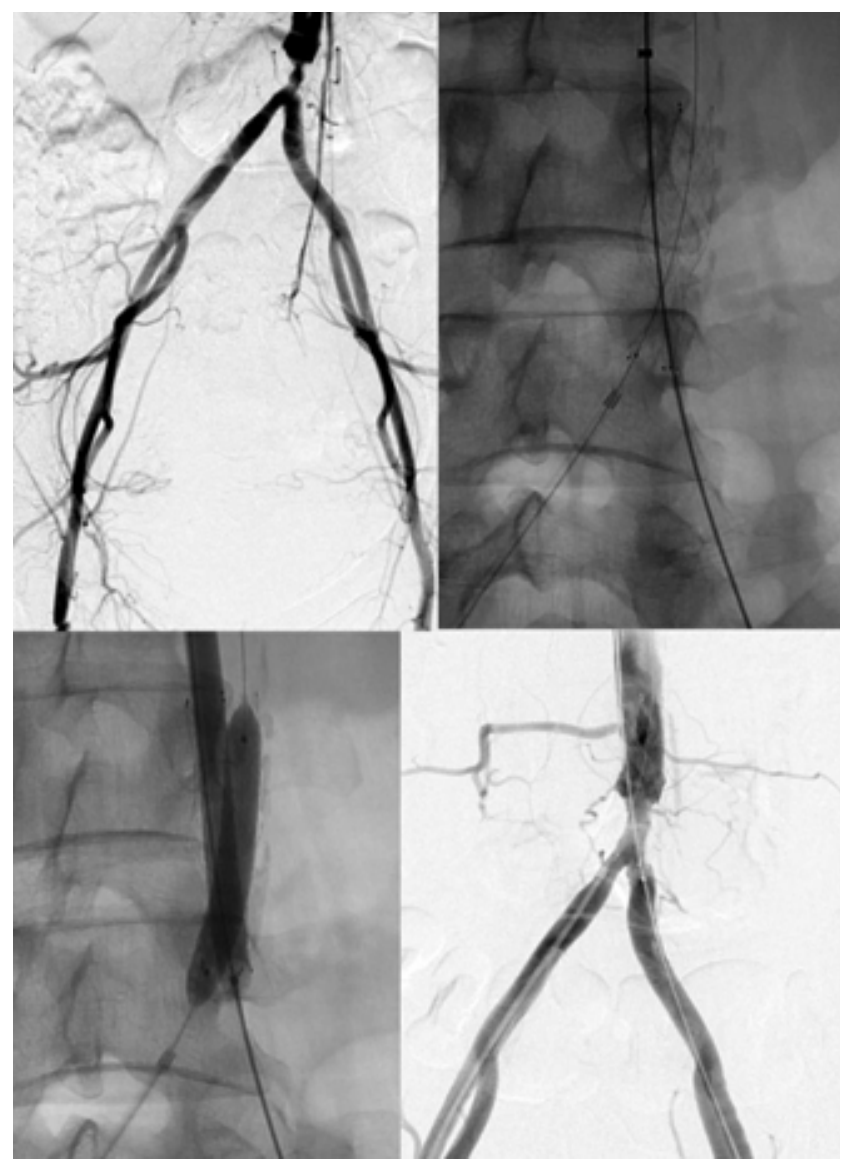

1. ábra

Fiatal - 38 éves - nőbeteg aortaszúkülete, amelyet transbrachialisan bevezetett nitinolstenttel és ballonos tágítással kezeltünk A beteg 20-30 m-es dysbasiás távolság (farpofa és alsó végtagi claudicatio jelentkezett) és alig tapintható femoralis pulzus miatt került vizsgálatra. A beavatkozás után azonnal panaszmentessé vált

atheroscleroticus szúkületek (például hystiocytosis okozta) (2. ábra) esetében kevesebb evidencia áll rendelkezésünkre, de a ballonos tágítás jó megoldást jelenthet a mütétre alkalmatlan betegeknél [6]. Atheroscleroticus szúkületek esetén nem teljesen tisztázott, hogy a csak tágítással kezelt betegek vagy primeren stentelt esetek profitálnak-e többet a beavatkozásból. A beavatkozás szövődményei közé tartozik a ruptura, a dissectio, az álaneurysma-képződés és a distalis embolisatio. A szövődmények ellátása történhet endovascularisan (például fedett stentimplantáció ruptura esetén) vagy sebészi feltárásból (például thrombectomia distalis embolisatio esetén). Az aorta fokális, atheroscleroticus szúkületeinél vagy rövid elzáródásainál javasolt az endovascularis terápia, mivel biztonságos, hatékony és általában klinikai sikerrel is jár, kedvező hosszú távon a nyitva maradása és alacsony a szövődményrátája. Primer stentimplantáció javasolt az excentrikus, egyenetlen felszínü és meszes szúkületeknél vagy elzáródásoknál, valamint a komplikációk elkerülése végett. 


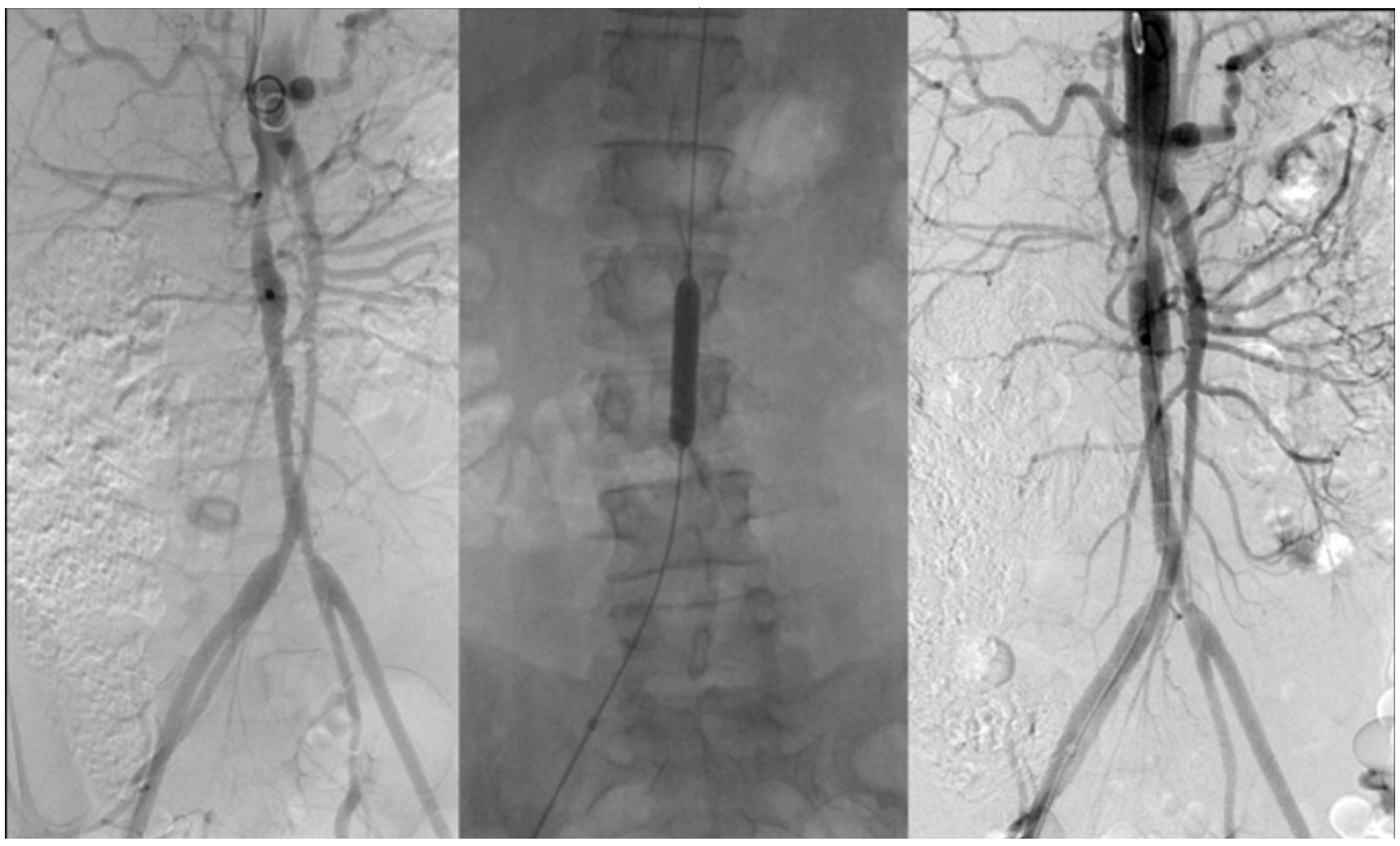

2. ábra

Non-Langerhans-sejtes hystiocytosisban (hisztológiailag verifikált Erdheim-Chester-betegség) szenvedő fiatal nő aortogramja ballonos tágítás előtt és után. A beteg panaszai azonnal elmúltak. A beavatkozás előtt $20 \mathrm{~m}$-es dysbasiás távolsága volt, a beavatkozás után nem számolt be claudicatióról (A 24 hónapos utánkövetés során végig panaszmentes volt)

\section{Veseartéria tágítása}

A renalis artéria tágítása és stentbehelyezés világszerte évtizedek óta történik anélkül, hogy egyértelmú klinikai bizonyíték lenne hatékonyságáról. Atheroscleroticus veseartéria-szúkület esetében, amely magasvérnyomás-betegséggel vagy krónikus veseelégtelenséggel jár, egyre több eredmény szól arról, hogy önmagában a gyógyszeres kezelés van annyira hatékony, mint az invazív beavatkozások közé tartozó stentelés és a gyógyszeres kezelés együtt [7]. A nyugati társadalomban a veseartéria-szúkületek leggyakoribb oka az atherosclerosis. Kockázati tényezői közé tartozik a magasvérnyomás-betegség, a dohányzás és a hyperlipidaemia. A 60 év feletti, veseelégtelenségben szenvedő betegek 25\%-ában az atheroscleroticus renalis artéria szülkülete felel a veseelégtelenségért [8]. Veseartéria-szúkületet okozhat az atherosclerosison kívül még a fibromuscularis dysplasia vagy a vasculitis is. Bár az ischaemiás vesebetegség és a hypertonia kezelésében nem bizonyított a veseartéria-tágítás és/vagy -stentelés előnye, van néhány kórállapot, amikor indokolt elvégezni. Fibromuscularis dysplasia általában fiatal vagy középkorú nők betegsége, veseartéria-szúkületük rendszerint ballonos tágítással megszüntethető, ritkán kerül sor stentbeültetésre. Flash pulmonalis oedemában indokolt lehet a veseartéria-tágítás, bár a pontos patomechanizmus nem teljesen tisztázott. Malignus hypertoniában vagy gyógyszeresen nem kontrollálható magas- vérnyomás-betegségben szintén ajánlott a veseartéria tágítása vagy stentelése, annak ellenére, hogy a betegek harmadában semmilyen javulás nem várható a beavatkozástól. Az eddig említett indikációkon kívül hypertoniában szenvedő gyermekeknél javasolt még a tágítás, abban az esetben, ha a szúkületet fibromuscularis dysplasia vagy neurofibromatosis okozza. Azoknál a betegeknél, akiknél rapid vesefunkció-romlás tapasztalható megtartott veseméret mellett, megkísérelhető a veseartéria-tágítás elvégzése veseprezerváció céljából, hiszen ezek a betegek rövid időn belül vesepótló kezelésre kerülnek. Az atheroscleroticus szúkületek rendszerint az eredést érintik (az aortától < $10 \mathrm{~mm}$-re vannak), míg a fibromuscularis dysplasia a veseartéria bármelyik részét érintheti, angiográfia során jellegzetes gyöngyfüzérszerű rajzolatot mutatva.

Míg az atheroscleroticus szúkület esetében nem teljesen egyértelmü, hogy melyik betegcsoport profitál a legtöbbet a beavatkozásból, addig a fibromuscularis dysplasia esetében nem ez a helyzet. Nagy esetszámú retrospektív vizsgálatokat felvonultató metaanalízis alapján a betegek akár $50 \%$-ában normalizálódhat a vérnyomás a tágítást követően gyógyszeres terápia nélkül [9]. A betegeknél a beavatkozás előtt hasi angiográfiát végzünk (CTA vagy DSA), majd transfemoralis, transaxillaris, transbrachialis vagy akár transradialis behatolásból a veseartéria szelektív katéterezése történik. A szúkületen 


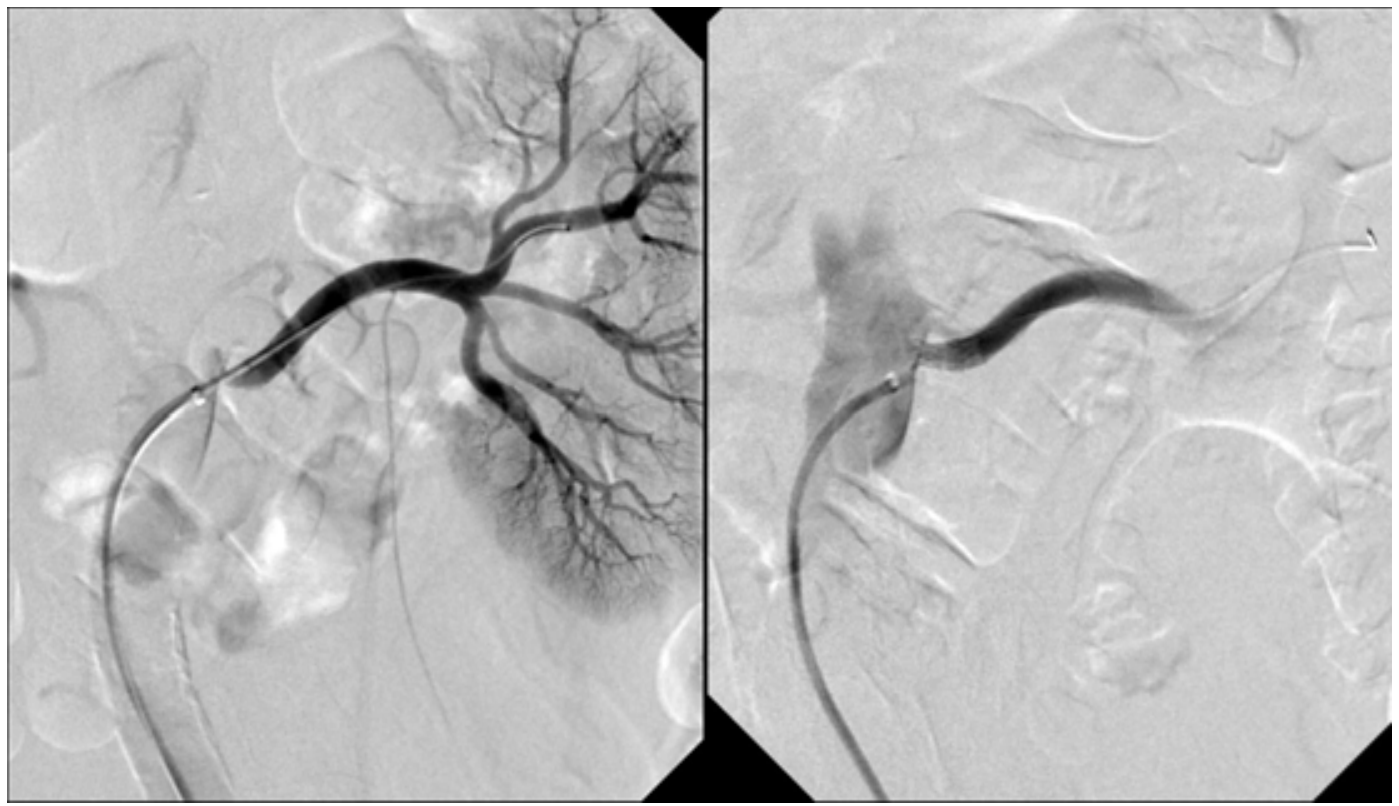

3. ábra

| Atheroscleroticus, ostialis renalis artéria szúkület ballonra helyezett stenttel történő tágítása

való átjutás után elvégezhető a ballonos tágítás [10]. A ballonos tágítás önmagában rendszerint elegendő, azonban szükség esetén, a veseartéria nyitva maradása érdekében, stentimplantációra is sor kerülhet. Az eredésbeli (ostialis) szúkületek esetén a hosszú távú nyitva maradás érdekében primeren stentbeültetés történik [11]. Atheroscleroticus szúkületek esetében, ha ostialis szúkületról van szó, a stentnek az eredést le kell fednie úgy, hogy 1-2 mm-rel az aortába nyúlik (3. ábra). Renalis artéria szúkületeinél ballontágítású és nem öntáguló stentet használunk, mivel milliméternyi pontossággal kell pozicionálni a stentet. Általában 5-6 mm átmérőjű, 12-20 mm hosszú stentet használunk erre a célra. A renalisartéria-intervenciók szövődményrátája magas, akár az esetek 20-25\%-át is érinthetik [12]. Leggyakoribb szövődmény a koleszterinembolisatio, ami akár minden tizedik esetben bekövetkezhet, és a tökéletes angiológiai eredmény ellenére fokozatos vesefunkció-romláshoz vezet. A ritka szövődmények közé tartozik a veseartéria-dissectio és a vesetok-perforáció. Ellentétben egyéb más perifériás intervencióval, a dissectiót követően a valódi lumen katéterezése rendkívül nehéz, szinte lehetetlen. A vesetok-perforáció térfoglaló retroperitonealis vérzéssel járhat, amely könnyen életet veszélyeztető vérzéses sokkhoz vezethet.

\section{Iliofemoralis artériák endovascularis kezelése}

Claudicatio intermittens általában az első tünete az alsó végtagi, krónikus, perifériás veróérbetegségnek. Az iliacalis és femoralis artériák stenoocclusiv betegségének hátterében az esetek döntő hányadában itt is az atherosclerosis áll. Az iliofemoralis artériák obliteratív beteg- sége, claudicatio intermittensen túl, okozhat akut ischaemiát, kritikus végtagischaemiát vagy blue toe szindrómát. Az utóbbi hátterében kifekélyesedett plakk okoz koleszterinkristály- vagy atheroma-mikroembolisatiót a láb végartériáiban. Az alsó végtagi krónikus perifériás verőérbetegség az 55-75 éves kor közötti korcsoport 5\%-át érinti, nemre való tekintet nélkül, míg a 70 év felettiek 20\%-ban érintettek. A betegek egy részében a tünetek nem romlanak vagy akár javulhatnak is megfelelő gyógyszeres kezelés és mozgásterápia mellett. $\mathrm{Az}$ életminőséget korlátozó dysbasia további kezelést tesz indokolttá, amely lehet endovascularis vagy sebészi $[1,13]$. Az iliacalis artériák esetében endovascularis kezelés javasolt izolált arteria iliaca communis vagy externa elzáródásakor (amennyiben az utóbbi nem terjed bele az arteria femoralis communisba), vagy ha az iliacalis artériák szúkülete összesen nem haladja meg a 10 $\mathrm{cm}-\mathrm{t}$ (4-5. ábra). Femoralis artériák esetében elsődlegesen az endovascularis kezelés javasolt, amennyiben a multiplex szúkületek egyenként nem érik el az $5 \mathrm{~cm}-\mathrm{t}$, vagy a hosszú szakaszú (<15 cm-es) beszúkült vagy elzáródott érterület nem terjed a térdízület alá. A tünetképző, atheroscleroticus iliacalis szúkületek esetében az angioplastica igen hatékony, a sikerarány 90-95\% között van. Az 5 éves nyitva maradás az $5 \mathrm{~cm}$-nél rövidebb szükületek esetében magas, eléri a 80-90\%-ot. A nyitva maradás esélye csökken az elzáródások, a súlyosan meszes és a $10 \mathrm{~cm}$-nél hosszabb szúkületek esetében [14]. Femoralis artériák esetében az endovascularis kezelés után egy évvel a kezelt érszakasz nyitva maradása már sokkal csekélyebb, nem éri el az 50\%-ot. A femoralis régióban a legjobb eredmények ballonos tágítás esetén az $5 \mathrm{~cm}$-nél rövidebb, nem diabeteses betegek esetén várhatók, akiknek cruralisan háromeres kiáramlási pályájuk van. Ennél hosszabb szúkületek vagy elzáródások esetén, diabeteses 


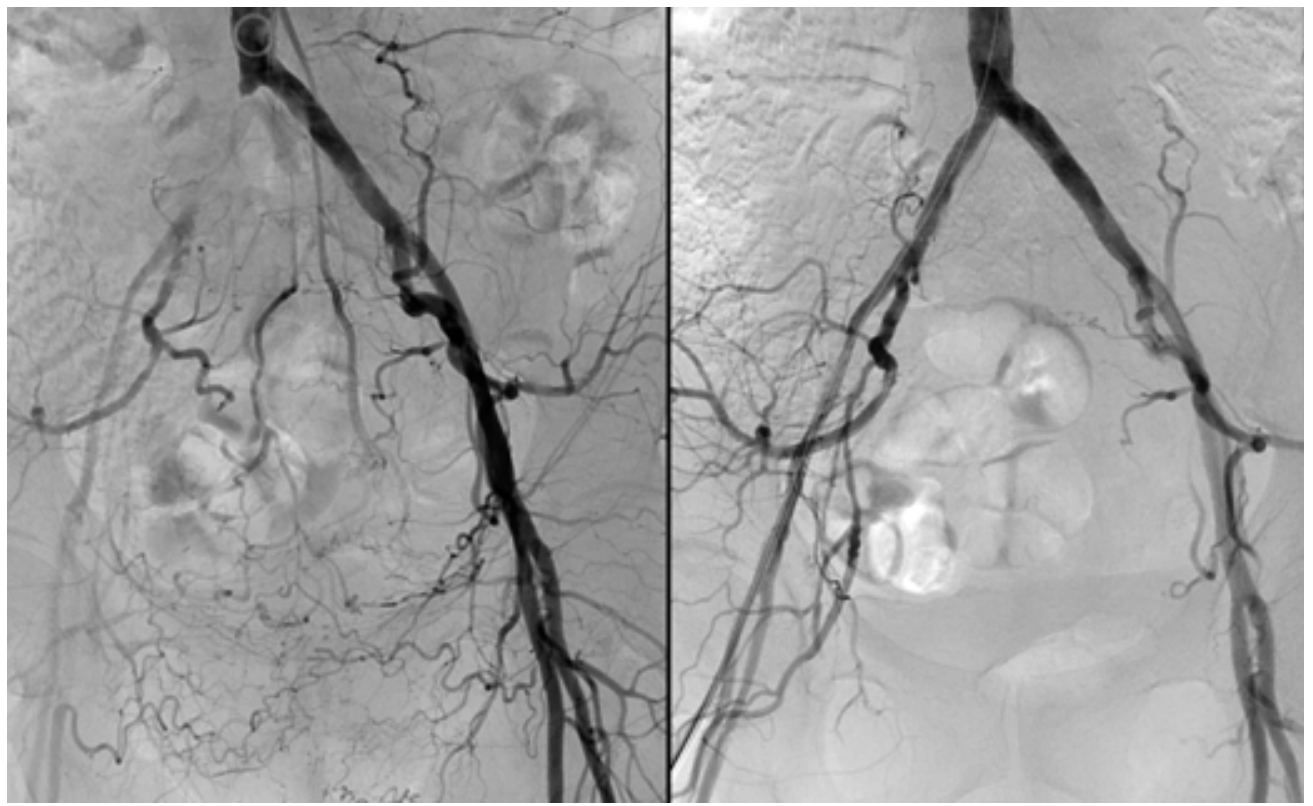

4. ábra

Középkorú nőbeteg, akinek 20 m-es dysbasiás távolsága van, majd jobb oldalon farpofa- és lábikragörcse jelentkezik. A beavatkozást követően elmúlt a claudicatio intermittense

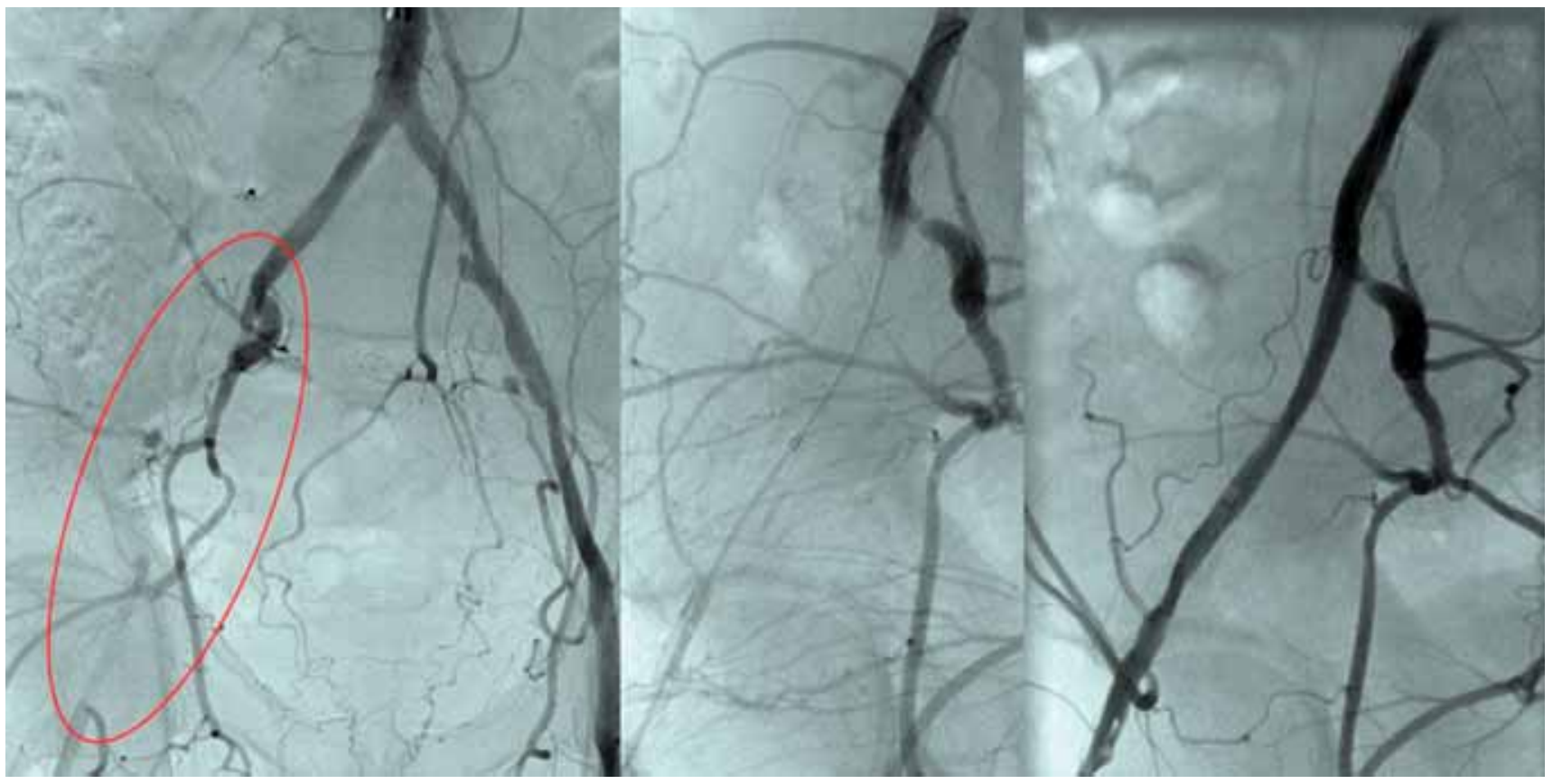

5. ábra | Középkorú férfi beteg, 10 m-es dysbasiás távolsággal. A beavatkozást követően claudicatióra nem panaszkodott

betegeknél vagy súlyosan meszes érrendszerben a stent javítja a hosszú távú eredményeket [15]. Az iliofemoralis artériák szúkületeinek vagy elzáródásainak endovascularis kezelése során a szövődmény veszélye 5\% körüli. A beavatkozás során a tágított szakasz akut elzáródása vagy rupturája, illetve a distalis embolisatio komoly problémát jelenthet, kezelésük lehet endovascularis vagy sebészi. Mivel a sikertelen endovascularis ke- zelés nem korlátozza a sebészi megoldást, de a sebészeti beavatkozáshoz képest jelentősen alacsonyabb a perioperatív mortalitás, így elsőként az endovascularis rekanalizáció javasolt. Még vita folyik arról, hogy mikor javasolt primeren stentet beültetni és mikor elég csak a hagyományos ballontágítás. Mindezek ellenére a perifériás érbeteg számára az endovascularis kezelés jelentős életminőségbeli javulást kínál. 


\section{A kritikus végtagi ischaemia katéteres kezelése}

A kritikus végtagi ischaemia (critical limb ischemia CLI) krónikus és akut formában létező, amputációs veszélyt jelentő, komplex, súlyos, önmagában irreverzíbilis anyagcserehelyzet [16, 17]. Definíciója: nyugalmi ischaemiás végtagfájdalom, szövetkárosodás (fekély, gangraena) megléte és a kar és a boka szintjén mért vérnyomásból számított boka/kar index (vagy az 1. ujjon mért vérnyomás, vagy transcutan szöveti oxigénmérés) kóros értéke.

A számos, kaszkádszerúen egymásba kapaszkodó (szénhidrát-anyagcsere, humorális, neuralis, ortopédiai, infektológiai, bőrgyógyászati és vascularis) tényezőből itt a cukorbetegség talaján kialakuló és döntően a térd alatti területek artériás rendszerét érintő úgynevezett diabeteses angiopathia jelenségével foglalkozunk.

Magyarországon a cukorbetegség előfordulása folyamatosan növekszik és jelenleg a latens esetekkel együtt a lakosság közel 10\%-át érinti. A mozgáshiányos és cukorháztartási zavarban szenvedő lakossághányad folyamatos növekedése mellett nem meglepő, hogy évente közel 40000 CLI keletkezik, és - döntően ennek következtében - több mint 6000 major amputációt végeznek hazánkban. Megfordítva: a major amputációk 85\%-a mögött az alsó végtag térd alatti artériás rendszerének súlyos diabeteses stenoocclusiója miatt kialakuló CLI áll [18]. Ez az amputációs szám a lakosságszámra vetített amputációs világátlag közel négyszerese. A CLI és a major amputáció olyan súlyos testi és lelki egészséghátrányt, „önsorsrontó” folyamatot, családi terhet, valamint az egészségügyi közfinanszírozásban olyan költséget jelent, ami a daganatok okozta terhekkel vetekszik.

Mint minden civilizációs betegségre, a CLI kezelésére is igaz, hogy a kezelés igazán eredményes és leginkább költséghatékony módja a megelőzés. Sajnos, a táplálkozás és a mozgásszegény életmód megváltoztatására tett társadalmi erőfeszítések már létező elemei jelenleg nem

\footnotetext{
A CLI ellátása sokszakmás, szigorú algoritmusba rendezett, szük időablakú eseménysor

- első teamdöntés (triage) 1-36 óra

- necroctomia

- vércukor/antibiotikus „elsősegély"

- státusfelmérő vizsgálatok (funkcionális és képalkotó)
}

gyors (és elégséges) revascularisatio

- második teamdöntés (re-triage) 48 órán túl

- rekonstrukciós mútét(ek)

- diabetológiai/infektológiai beállítás

- angiológiai kezelés

- rehabilitáció kapcsolódnak rendszerbe, nem érik el a „kritikus tömeget”. Hatásuk szerencsés esetben is csak évtizedek múlva lesz mérhető. Addig a mind nagyobb számban jelentkező CLI gyors és rendszerszintű, többszakmás kezelésével tudjuk az amputációk számát csökkenteni.

Ha jelen ismereteink szerint a CLI-be torkolló kaszkádszerü folyamat kulcseleme a szöveti oxigénszint tartósan alacsony volta, aminek hátterében elsősorban az artériás keringés károsodása áll, akkor érthető, hogy a végtagmentő terápia kulcseleme is a gyors, lehetőleg minimálisan invazív revascularisatio.

Számos európai országban a CLI ellátására szervezett sokszakmás munkacsoportokban az ellátás kötött algoritmusban zajlik (6. ábra).

A CLI esetében csaknem mindig az alsó végtag artériás rendszerének egyszerre több szintje érintett. A revascularisatiónál cél és elvárás, hogy azt a végtag keringését egységes rendszernek tekintve, lehetőleg a többszintű és eltérô patomorfológiai (arteriosclerosis az iliofemoralis szinten és diabeteses angiopathia a térdtól distalisan) stenoocclusiót egy ülésben lássuk el. A térd szintjében az arteria poplitea és a térd alatti (BTK: below the knee) területen a kiáramlási pályák gyakran nem meszes, hoszszú szakaszú és szimultán elváltozásaival találkozunk. (Ezért hamis az a feltételezés, hogy a BTK-terület ellátása a koszorúerek revascularisatiójának analógiái alapján közelíthető meg.) A BTK-revascularisatio során a háromeres kiáramlási pálya eltérése és a szövetkárosodás helye alapján a járásképesség megmaradásának elsődleges célját szem előtt tartva kell a rekanalizáció célterületét meghatároznunk. Ebben az egyik - a plasztikai sebészetból átemelt - szempontrendszer az angiosoma koncepció (7. ábra). Az intervenciós radiológiai, minimálisan

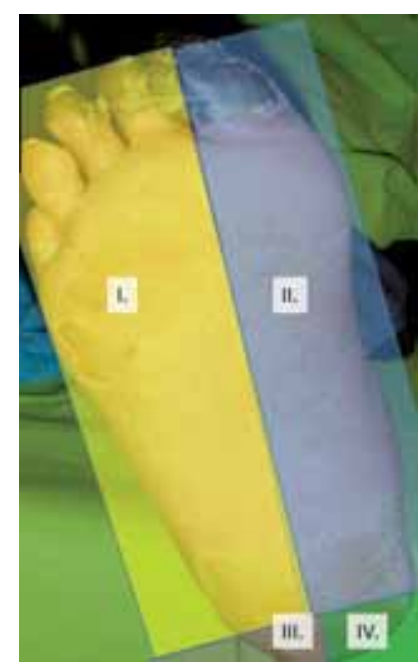

7. ábra Az ischaemiás szövetkárosodás helyéből és az egyes artériák típusos ellátási területének ismeretéból nagy biztonsággal megjósolható az érkárosodás helye. Az ellátási területek (angiosomák: I. a. plantare laterale; II. a. plantare mediale; III. ramus calcaneus a. peroneae; IV. ramus calcaneus a. tibialis post.; nem látszik az ábrán az a. tibialis ant. és post. területe) és a három alszári artéria szokásos „helyettesítő múködésének” ismerete alapvető a rekanalizációs célterület optimális kiválasztásában és a funkcionálisan leginkább eredményt hozó rekanalizáció elvégzésében 


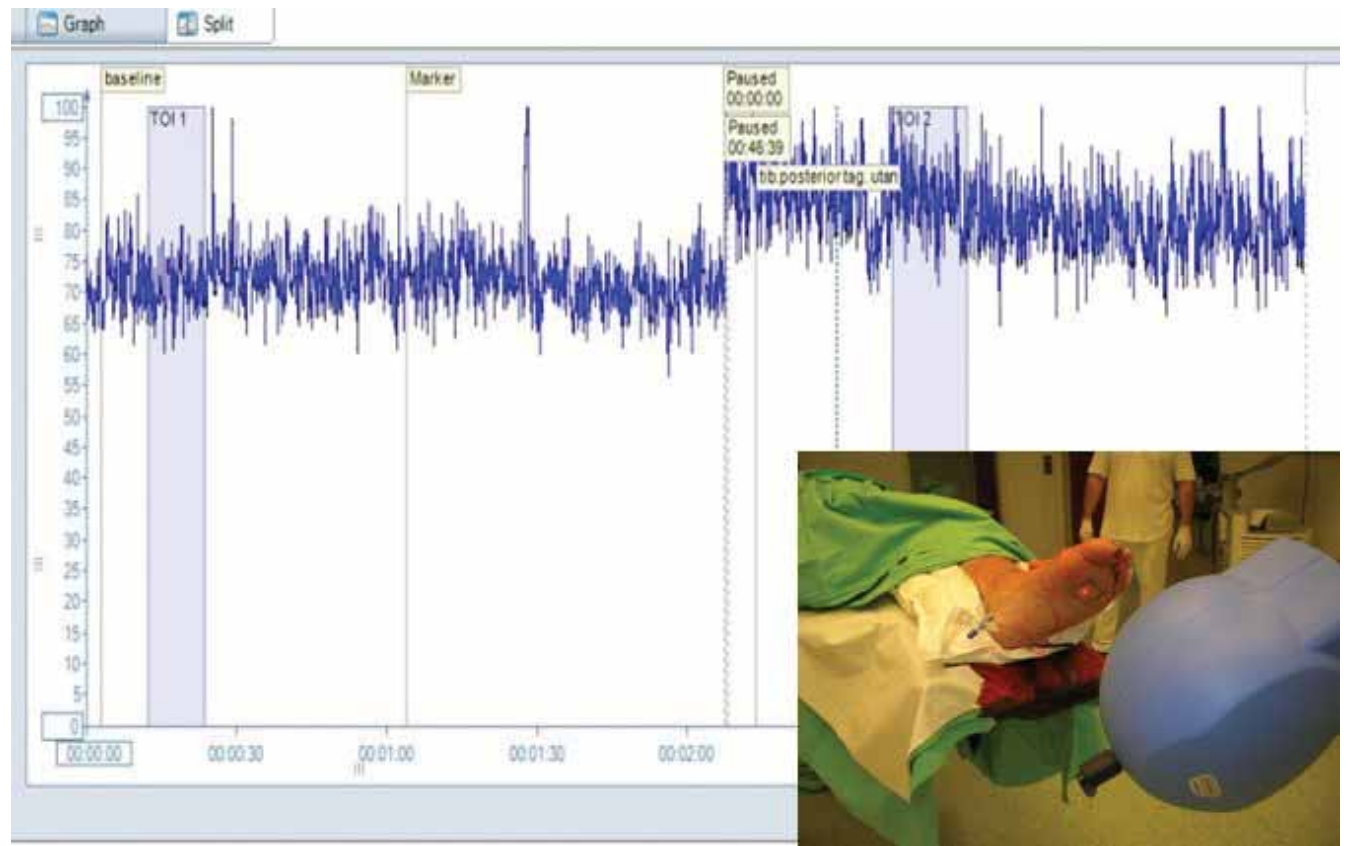

8. ábra

Egyidejü funkcionális mikrocirkuláció-vizsgálat Laser Speckle Contrast Analysis (LASCA) segítségével arteria tibialis posterior tágítása közben. A kis képen a talp egy kijelölt területén a non-contact mérést, majd a jobb oldalon a mérési térfogat tágítás előtti és tágítás utáni mikrocirkulációjának változását grafikusan és a keringésjavulás százalékos számszerúsítését láthatjuk
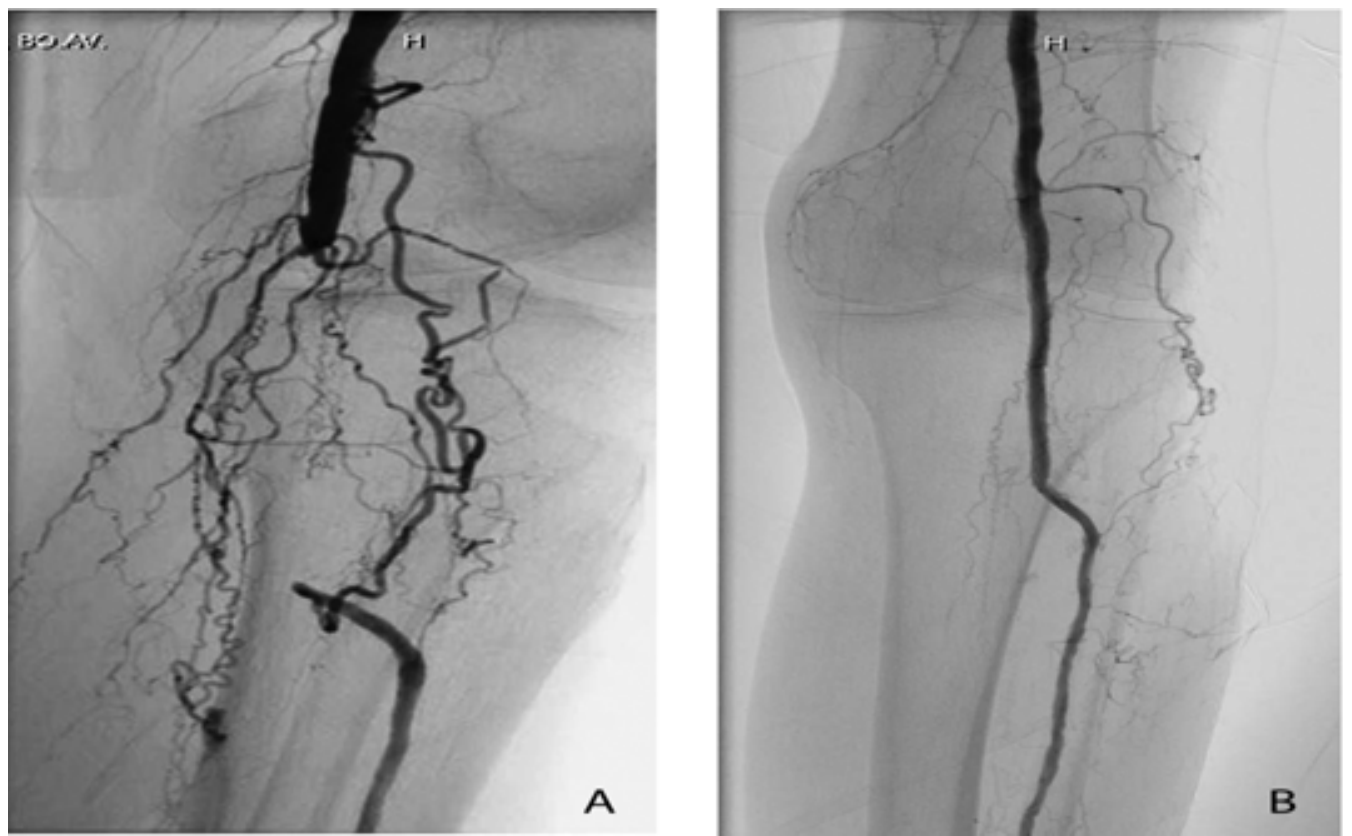

9. ábra

A poplitea II-III. szakasz teljes hiánya és a lábszári kiáramlás három eréból kettőnek az elzáródása (A) igen súlyos ischaemiát tart fenn a lábon és femoralis szintű amputációs kényszert jelent. Ezért ezekben az esetekben elsőnek választandó lépés az intervenciós radiológiai, endovascularis recanalisatio, mellyel esetünkben is nyitott mútét nélkül, kiváló haemodinamikai eredményú revascularisatiot értünk el (B)

invazív, altatást és feltárást nem igénylő revascularisatio rendkívüli előnye a nyitott sebészeti ellátással szemben, hogy a végtag rekanalizációjának eredménye morfológiailag (angiográfia) és funkcionálisan (Doppler-ultrahang, lézer-Doppler, szöveti oxigénmérés) a beavatkozás során azonnal (8. ábra) detektálható, és már órákkal a beavat- kozás után a végtag aktívan használhatóvá válik. A megfelelően feszes triászszemlélettel dolgozó, multidiszciplináris CLI-centrumokban végzett, többlépcsős lábmentési tevékenység jól dokumentálhatóan az amputációk csaknem 75-80\%-ának elkerülhetőségét eredményezik (910. ábra) $[19,20]$. 

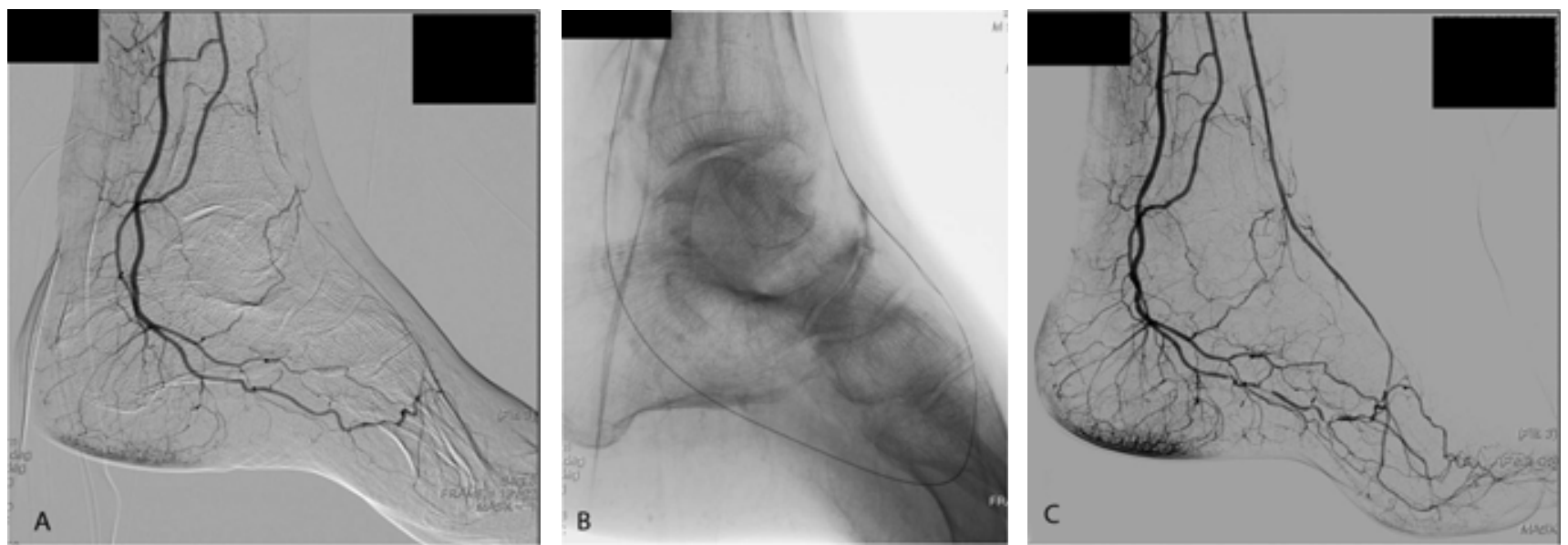

10. ábra

A láb kiegyensúlyozott keringésének feltétele a három lábszári ér megléte. Jelen esetben a tibiális anterior-dorsalis pedis occlusiója az előláb ischaemi áját és az I-I ujj gangrénáját eredményezi (A). Mivel a tibiális anterior anterográd recanalisatioját nem tudtuk elvégezni, ezért esetünkben a tibialis posterior - talpi ív - dorsalis pedis - tibialis anterior tengelyt használva, „retrograd” jutottunk a megnyitandó érszakaszba és rekonstruáltuk azt (B). A kontrollképen jól látható a megnyitott tibialis anterior - dorsalis pedis tengely és a lábelő keringésének markáns javulása (C)

Magyarországon az országos lefedettséget biztosító intervenciós radiológiai centrumokra szervezett diabetesesláb-központok és az érbetegek „vascularis team” által történő ellátásirányításának szakmai és kapacitáskeretei adottak. Amennyiben a betegutakat optimalizáló, ellátásszabályozási és -finanszírozási paraméterek a korai és többszakmás ellátási algoritmus „kényszerét” megteremtik, úgy látványosan csökkenthető lesz a világviszonylatban is kimagaslóan rossz hazai amputációs szám.

\section{Következtetések}

$\mathrm{Az}$ artériás endoluminalis revascularisatio tehát elérhető és egyes centrumokban megfelelő esetszámban, kellő rutinnal gyakorolt módszerek. Az angiológus, diabetológus, érsebész és intervenciós radiológus alkotta együttmúködő csoportok tudják leginkább a betegek, így a társadalom érdekeit szolgálni, a legjobb hosszú távú eredményeket elérni, a leginkább visszaadni a betegek munkavégző képességét és életminőségét. Ezek a centrumok azonban további fejlesztést igényelnek, mind technikai, mind finanszírozási, mind megfelelően képzett humán erôforrás szempontjából, hogy a betegek is minél nagyobb számban megtalálják a számukra valóban megfelelő ellátást biztosító helyeket.

Anyagi támogatás: A közlemény megírása anyagi támogatásban nem részesült.

Szerzői munkamegosztás: N. Cs.: Az aorta szúkületeinek és elzáródásainak endovascularis kezelése.Veseartéria tágítása. Iliofemoralis artériák endovascularis kezelése. B. Z.: A kritikus végtagi ischaemia katéteres kezelése.
A cikk végleges változatát valamennyi szerző elolvasta és jóváhagyta.

Érdekeltségek: A szerzőknek nincsenek érdekeltségeik.

\section{Irodalom}

[1] Norgren, L., Hiatt, W. R., Dormandy, J. A., et al.: Inter-society consensus for the Management of Peripheral Arterial Disease (TASC II). J. Vasc. Surg., 2007, 45(1Suppl.), S5-S67.

[2] Lumsden, A. B., Davies, M. G., Peden, E. K.: Medical and endovascular management of critical limb ischemia. J. Endovasc. Ther., 2009, 16 (2 Suppl. II), II31-II62.

[3] Shammas, N. W.: Epidemiology, classification, and modifiable risk factors of peripheral arterial disease. Vasc. Health Risk Manag., 2007, 3(2), 229-234.

[4] Crawford, E. S., Bomberger, R. A., Glaeser, D. H., et al.: Aortoiliac occlusive disease: factors influencing survival and function following reconstructive operation over a twenty-five-year period. Surgery, 1981, 90(6), 1055-1067.

[5] Lastovicková, J., Peregrin, J. H.: Primary self-expandable nitinol stent placement in focal lesions of infrarenal abdominal aorta: long term results. Cardiovasc. Intervent. Radiol., 2008, 31(1), $43-48$.

[6] Keith, D. S., Markey, B., Schiedler, M.: Successful long-term stenting of an atypical descending aortic coarctation. J. Vasc. Surg., 35(1), 166-167.

[7] Cooper, C. J., Murphy, T. P., Cutlip, D. E., et al.: Stenting and medical therapy for atherosclerotic renal-artery stenosis. N. Engl. J. Med., 2014, 370(1), 13-22.

[8] Mailloux, L. U., Bellucci, A. G., Napolitano, B., et al.: Survival estimates for 683 patients starting dialysis from 1970 through 1989: identification of risk factors for survival. Clin. Nephrol., 1994, 42(2), 127-135.

[9] Chrysant, S. G., Chrysant, G. S.: Treatment of hypertension in patients with renal artery stenosis due to fibromuscular dysplasia of the renal arteries. Cardiovasc. Diagn. Ther., 2014, 4(1), 3643.

[10] Ruzsa, Z., Tóth, K., Jambrik, Z., et al.: Transradial access for renal artery intervention. Interv. Med. Appl. Sci., 2014, 6(3), 97103. 
[11] Van de Ven, P. J., Kaatee, R., Beutler, J. J., et al.: Arterial stenting and balloon angioplasty in ostial atherosclerotic renovascular disease: a randomised trial. Lancet, 1999, 353(9149), 282-286.

[12] Beek, F. J., Kaatee, R., Beutler, J. J., et al.: Complications during renal artery stent placement for atherosclerotic ostial stenosis. Cardiovasc. Intervent. Radiol., 1997, 20(3), 184-190.

[13] Siracuse, J. J., Giles, K. A., Pomposelli, F. B., et al.: Long-term results for primary bypass vs. primary angioplasty/stent for intermittent claudication due to superficial femoral artery occlusive disease. J. Vasc. Surg., 2012, 55(4), 1001-1007.

[14] Tetteroo, E., van der Graaf, Y., Bosch, J. L., et al.: Randomised comparison of primary stent placement versus primary angioplasty followed by selective stent placement in patients with iliacartery occlusive disease. Dutch Iliac Stent Trial Study Group. Lancet, 1998, 351(9110), 1153-1159.

[15] Bachoo, P., Thorpe, P. A., Maxwell, H., et al.: Endovascular stents for intermittent claudication. Cochrane Database Syst. Rev., 2010, (1), CD003228. doi: 10.1002/14651858.

[16] Chisci, E., Perulli, A., Iacoponi, F., et al.: Benefit of revascularisation to critical limb ischaemia patients evaluated by a patientoriented scoring system. Eur. J. Vasc. Endovasc. Surg., 2012, $43(5), 540-547$.
[17] Shishehbor, M. H., Reed, G. W.: Personalized approach to revascularization of critical limb ischemia. Circ. Cardiovasc. Interv., 2014, 7(5), 642-644.

[18] Setacci, C., de Donato, G., Teraa, M., et al.: Treatment of critical limb ischaemia. Eur. J. Vasc. Endovasc. Surg., 2011, 42(Suppl. 2), S43-S59.

[19] Sultan, S., Hynes, N.: Five-year Irish trial of CLI patients with TASC II type C/D lesions undergoing subintimal angioplasty or bypass surgery based on plaque echolucency. J. Endovasc. Ther., $2009,16(3), 270-283$.

[20] Nakano, M., Hirano, K., Yamauchi, Y., et al.: Three-year clinical outcome after infrapopliteal angioplasty for critical limb ischemia in hemodialysis patients with minor or major tissue loss. Catheter Cardiovasc. Interv., 2014 Sep 25. doi: 10.1002/ccd.25676. [Epub ahead of print]

(Doros Attila dr., Budapest, Baross u. 23., 1082 e-mail: doros.attila@med.semmelweis-univ.hu)
A Markusovszky Lajos Alapítvány Kuratóriuma és az Akadémiai Kiadó meghívja Önt

az Orvosi Hetilap Szerkesztőbizottságának és Szerkesztőségének hagyományos évi Markusovszky Lajos-emlékülésére.

Időpont: 2015. május 6. (szerda) 10:30

Helyszín: az Aesculap Akadémia konferenciaterme (Budapest XI., Halmi u. 20-22. - Tétényi út 12-16. sarok)

Az ünnepségre szeretettel várjuk!
Program: Az Orvosi Hetilap - Markusovszky Lajos Alapítvány és a Dr. Fehér János Emlékére Alapítvány 2015. évi kitüntetéseinek ünnepélyes átadása

- „Orvosi Hetilap Markusovszky Lajos-emlékérem”

- "Orvosi Hetilap Markusovszky Lajos-dij”

- Referensek munkájának elismerése

- „Dr. Fehér János Emlékére Alapítvány-díj” átadása és a díjazottak előadásai

\section{Markusovszky Lajos-emlékelőadás}

Prof. Dr. Hunyady Béla: Áttörés a hepatitis C kezelésében: a fertőzés felszámolása ma már kizárólag anyagi kérdés

Fogadás

Kérjük, jelezze részvételi szándékát Budai Editnél a budai.edit@akkrt.hu e-mail címen. 